\title{
Possible Association between Th1 Immune Polarization and Epithelial Permeability with Toll-Like Receptors 2 Dysfunction in the Pathogenesis of the Recurrent Aphthous Ulceration
}

\author{
Fabiana M. Barros, ${ }^{1}$ Mônica A. Lotufo, ${ }^{1}$ Priscila M. Andrade, ${ }^{1}$ \\ Cristiane M. França, ${ }^{2}$ and Ricardo C. Borra ${ }^{1}$ \\ ${ }^{1}$ São Leopoldo Mandic Dental Research Institute, Campinas, SP 03316-000, Brazil \\ ${ }^{2}$ Dental School, University Nove de Julho, SP, Brazil \\ Correspondence should be addressed to Ricardo C. Borra, rcborra@gmail.com
}

Received 2 November 2009; Accepted 12 February 2010

Academic Editor: Tetsuo Arakawa

Copyright ( $) 2010$ Fabiana M. Barros et al. This is an open access article distributed under the Creative Commons Attribution License, which permits unrestricted use, distribution, and reproduction in any medium, provided the original work is properly cited.

\begin{abstract}
Recurrent Aphthous Ulceration (RAU) is a chronic oral inflammatory disease that affects approximately $25 \%$ of the general population. The etiology of the disease is unknown; however, factors that favor the onset of RAU have been correlated with a Th1 immune polarization, while factors that reduce RAU episodes have been associated with down regulation of immune reaction or stimulation of the peripheral tolerance. In this context, the integrity of the epithelial barrier is also fundamental for the prevention of the disease and conditions that augment its permeability or produce disruption are considered potential triggers. The key factor responsible for increased susceptibility is unclear, though a deficiency of Toll-like receptor (TLR) activity seems to be a good candidate. TLRs are a group of membrane proteins that recognize conserved molecules derived from bacterial, virus, fungal, or host tissues. Particularly, the TLR2 is involved in both immune regulation and control of epithelial barrier integrity. Thus, based on literature review, we showed evidences that correlate the TLR2 dysfunction and the diverse predisposing factors with the elements considered critical for disease pathogenesis: the Th1 immune reaction and the increased epithelial permeability.
\end{abstract}

\section{Background}

Recurrent Aphthous Ulceration (RAU) is a chronic oral inflammatory disease of unknown pathogenesis that affects approximately $25 \%$ of the general population. RAU affects both sexes equally and decreases in occurrence after 45 years of age. Clinical manifestations of RAU range from mild ulcerations that heal within a few days to multiple, deep, and painful ulcers that can persist for up to six weeks. Often, the lesions affect nonkeratinized mobile areas of the oral cavity such as the buccal and labial mucosa, the lateral and ventral tongue, the floor of the mouth, and the soft palate. Local and systemic predisposing factors, such as stress, smoking cessation, nutritional deficiency, nonsteroidal anti-inflammatory drugs (NSAIDs), beta-blockers, nonbreastfeeding history, hormonal changes, or trauma in addition to others, have been associated with RAU onset [1].
Clinical and experimental evidence suggests that a reduced ability to activate immune tolerance plays a role in the pathogenesis of some gastrointestinal inflammatory diseases. It has been proposed that the induction of tolerance in the mucosa may reflect a preferential activation of Th2- and/or T regulatory responses. In RAU, genetic and environment factors affecting the Th1/Th2 balance may contribute to low tolerance, thereby permitting a cytotoxic immune response against antigens present on normal oral epithelium that are similar to foreign ones. However, the existence of such conditions does not provide an explanation for the fact that in the majority of the cases, the lesions are restricted to nonkeratinized mucosa from oral cavity. Probably a failing of the epithelial barrier must occur in parallel with an infection agent for activation of the disease.

The main factor responsible for the occurrence of these events is unknown, though a deficiency of TLR activity 
seems to be a good candidate. The Toll-like receptors (TLRs) are a group of functional membrane receptors that recognize structurally conserved molecules derived mainly from bacterial, viral, fungal, and host tissue products that are involved in both immune regulation and control of epithelial barrier integrity. Therefore, the objective of this study is to debate the connections between RAU, Th1 immune polarization, and epithelial barrier deficiency with TLR2 dysfunction and with its factors associated.

\section{Literature Review}

Basically, two etiologic theories have been proposed to explain the development of RAU. The earliest theory, known as the bacteriological hypothesis, suggests that some bacteria or viruses such as streptococcus sanguis, Streptococcus viridians, Helicobacter pylori, Herpes simplex, and Epstein-Barr between other microorganisms are the main etiologic agents responsible for the development of RAU. In contrast, the immunological hypothesis correlates RAU development with an exaggerated cytotoxic type autoimmune response against epithelial cells. However, both theories are unsatisfactory when it comes to understanding the multiple variations involved with onset and outcomes of the disease, and the lack of comprehension of RAU has resulted in empirical strategies for treatment development. Here, we reviewed evidences that connect both theories in a multifactorial model disease based on immune and epithelial dysfunction. Probably, a combination of genetic and environmental factor that affect the capability of immune control and mucosal permeability probably acts as potential trigger for RAU onset.

2.1. The Genetic Susceptibility to RAU. The occurrence of the RAU is dependent of a genetic predisposition. Although no specific mode of inheritance could be established, it is common to find out familial history in patients carrier of RAU [2], mainly in monozygotic twins [3]. Probably, cluster of genes may be involved in RAU phenotypes. The existence of genetic polymorphisms for TNF- $\alpha$, IL- $1 \beta[4,5]$, and IL- 6 [5] and promoter region of serotonin transporter (5-HTT) [6] genes was demonstrated in RAU patients in comparison with healthy control subjects. Increased frequency of certain human leukocyte antigen (HLA) types as HLA-Cw7 [7] HLA-B51 [7, 8], HLA-B52, and HLA-B44 [9] was observed among RAU patients.

2.2. Th1/Th17/Th2 Imbalance in RAU. The development of various autoimmune diseases seems to be related to polarization of the immune response. RAU is characterized by Th1 polarization [10] and is thus similar to other chronic inflammatory diseases that involve the gastrointestinal tract, such as orofacial granulomatosis [11], Crohn's disease, and celiac disease [12]. Many factors that favor or trigger the onset of RAU, such as stress, NSAIDs, beta-blocker medications, TLR7 agonist (imiquimod) [13, 14], food, and hematic deficiencies, are also related to an increase in the Th1-type immune responses (Table 1). On the other hand, factors that reduce RAU onset such as cigarette smoking, TNF inhibitors, thalidomide, breast feeding history, and pregnancy have previously been associated with a stimulation of peripheral immune tolerance (Table 1). Therefore, it is likely that in Th1-disease-susceptible patients, there is an improper and imbalanced immune response to stimuli that would normally be neglected by a healthy immune system, and this sensitivity may be further intensified by the diverse conditions that create an imbalanced Th1/Th2 immune response. Recently, a new subset of lymphocytes, known as Th17 for their ability to produce IL-17A, was described. The predominant function of Th17 cells is thought to be proinflammatory due their ability to recruit neutrophils and to enhance the synthesis of inflammatory cytokines, chemokines, matrix metalloproteinases, and defensin by epithelial cells. Although there are no data currently available, Th17 cells may also be involved in RAU pathogenesis, as Th17 cells were recently implicated in other chronic gastrointestinal Th1 inflammatory diseases [15].

2.3. The Importance of TLR Activity in RAU. Among the proinflammatory cytokines, TNF- $\alpha$ appears to play key role in the pathogenesis of RAU. Peripheral blood mononuclear cells (PBMC) from RAU patients are able to secrete higher amounts of TNF- $\alpha$ than control groups $[18,19]$, the expression of TNF- $\alpha$ mRNA in RAU lesions is higher than that in traumatic ulcers [18] and medications that decrease TNF- $\alpha$ activity such as thalidomide [43], and the biological TNF inhibitors such as pentoxifylline, tetracycline, etanercept, infliximab, and adalimumab [44-46] are effective in improving outcomes of RAU patients. TNF- $\alpha$ is known to be a critical cytokine in Th1 chronic diseases like psoriasis, Behçet's disease, rheumatoid arthritis, and Crohn's disease [47].

The production of TNF- $\alpha$ is mostly mediated by activation of TLRs, which are a group of 11 functional membranereceptors that recognize structurally conserved molecules called pathogen-associated molecular patterns (PAMPs), which are mainly derived from bacterial, viral, fungal, or host-tissue products. The specificity of TLR recognition has been established for several important PAMPs. Particularly, the TLR2 recognizes lipoteichoic acid (LTA), bacterial lipoproteins, zymosan, Pam3CSK4, host heat shock protein 60 (HSP60) HKLM (Heat-killed Listeria monocytogenes), among others [48].

Stimulation of specific TLRs influences the Th-response towards either Th1- or Th2-cytokine profiles, and this may explain the influence of antigen composition on the adaptive immune response. LPS (TLR4 agonist) preferentially induces the secretion of IL-12, which is considered a key cytokine for the Th1 immune response, and TLR2 ligands such as peptidoglycan, zymosan, and Pam3CSK4 induce IL-10 secretion and regulatory $\mathrm{T}$-cell responses, which have a strong inhibitory effect on the Th1-type immune response [49-52].

Because crosstalk exists between TLRs and their various ligands, the consequential inflammatory reaction likely depends upon the complex and the simultaneous TLR response [53]. Dendritic cells (DCs) and PMBCs, when exposed to various combinations of TLR2 agonists and TLR3 or TLR4 ligands and IFN- $\alpha$ or IFN- $\gamma$ cytokines, 
TABLE 1: Th1 polarization induced by factors associated with RAU.

\begin{tabular}{|c|c|c|}
\hline Factors & Observed effects & References \\
\hline \multirow{5}{*}{$\begin{array}{l}\text { Th1 polarization of } \\
\text { immune response } \\
\text { in the RAU }\end{array}$} & $\uparrow$ IL-2, IL-12, IFN- $\gamma$, and $\downarrow$ IL- 4 & {$[16]$} \\
\hline & $\uparrow \mathrm{TH} 1 / \mathrm{TH} 2$ diverse genes (microarray) & {$[10]$} \\
\hline & $\downarrow$ HSP27 and $\downarrow$ IL-10 & {$[17]$} \\
\hline & $\uparrow$ IFN- $\gamma$, TNF- $\alpha$, IL-2, IL-4, IL-5, and $\downarrow$ IL-10 & {$[18]$} \\
\hline & $\uparrow$ IFN- $\gamma$, TNF- $\alpha$, IL-2, IL-5, IL-6, IL- 8 and $\downarrow$ IL- 10 , and TGF- $\beta$ and $\downarrow$ CD $4^{+}$CD $25^{+}$ & [19] \\
\hline \multirow{4}{*}{ Stress } & $\uparrow$ IL-1, IL-6, IL-8, IL-18, and TNF- $\alpha$ & {$[20]$} \\
\hline & $\uparrow$ IFN- $\gamma$, TNF- $\alpha$ IL-6, IL-10, and IL-5 & {$[21]$} \\
\hline & $\uparrow$ IFN- $\gamma$, IL- 2 and $\downarrow$ IL- 10 , and IL-4 & {$[22]$} \\
\hline & $\downarrow$ inhibitory effect of catecholamines on IFN- $\gamma$ and failure to shift to Th2 responses & {$[23]$} \\
\hline \multirow{2}{*}{ NSAIDs } & $\uparrow$ TNF- $\alpha$ & [24] \\
\hline & $\uparrow$ IFN- $\gamma$, TNF- $\alpha$, IL- 2 and $\downarrow$ IL- 4 , and IL-6 & [25] \\
\hline \multirow{2}{*}{ Bromelain } & $\uparrow$ TNF- $\alpha$ and IFN- $\gamma$ & [26] \\
\hline & $\uparrow$ permeability of the mucosa & [27] \\
\hline Beta-blockers & Beta-blockers cause Th1 polarization & {$[28]$} \\
\hline $\begin{array}{l}\text { Imiquimod } \\
\text { (TLR7) }\end{array}$ & $\uparrow$ IFN- $\gamma$, IL-12, IL- 6 , and TNF- $\alpha$ & [29] \\
\hline \multirow{2}{*}{ Hypovitaminosis } & $\downarrow \mathrm{B} 12=\uparrow \mathrm{TNF}-\alpha$ and $\downarrow$ of EGF & {$[30]$} \\
\hline & $\downarrow \mathrm{B} 6=\uparrow \mathrm{TNF}-\alpha$ & {$[31]$} \\
\hline \multirow{3}{*}{ Cigarette smoking } & IFN- $\gamma /$ IL-10 (Th1/Th2) ratio is lower in smokers & {$[32]$} \\
\hline & $\downarrow$ IL-12 p40/IL-10 ratio & {$[33]$} \\
\hline & $\downarrow$ IL-2 and TNF- $\alpha$ & {$[34]$} \\
\hline Pregnancy & $\uparrow$ Th2/Th1 cytokines ratio & [35] \\
\hline Breatfeeding & $\uparrow$ regulatory $\mathrm{T}$ cells & {$[36]$} \\
\hline Thalidomide & $\downarrow$ TNF- $\alpha, \downarrow$ IL-12 and $\uparrow$ IL-10 (LPS stimulation) & {$[37,38]$} \\
\hline \multirow{3}{*}{ TNF inhibitors } & $\downarrow$ TNF- $\alpha$ and $\uparrow \mathrm{CD} 4^{+} \mathrm{CD} 25^{+}$in situ (Infliximab) & [39] \\
\hline & $\downarrow \mathrm{CD} 44^{+} \mathrm{CD} 25^{+}$spontaneous apoptosis (Infliximab) & {$[40]$} \\
\hline & $\downarrow$ TNF- $\alpha$, IL-2 and IFN- $\gamma$ (pentoxifylline) & [41] \\
\hline TLR2 deficiency & TLR2-induced anti-inflammatory responses ( $\uparrow$ IL-10) & {$[42]$} \\
\hline
\end{tabular}

block induction of a subset of Th1 genes. In DCs, TLR2 agonists are able to suppress induction of IP-10 and IL12 stimulated by LPS and double-stranded RNA-poly(I:C) (TLR3 agonist), which most likely induces the release of IL10 [50]. In Crohn's disease, a malfunction of TLR2 mediated by the NOD2/CARD15 gene mutation is responsible for lower production of the anti-inflammatory cytokine IL-10 in PBMCs stimulated with LTA or Pam3CSK4 but not with LPS [54].

In RAU, rupture of the oral mucosa originating from toothbrush abrasions, laceration by sharp foods, or injury caused by accidental biting often expose cells from the lamina propria to a variety of TLR ligands. In a recent paper, Borra et al. [47] demonstrated that the response profiles of PBMCs in healthy subjects or patients with simple or complex aphthosis stimulated with the TLR2 agonists Staphylococcus aureus LTA, PamC3SK4, and HKLM were different. PBMCs from control groups had the strongest TNF- $\alpha$ response to both LTA and Pam3CSK4, whereas a group of RAU patients with aggressive disease were highly responsive to HKLM. PBMCs from control and moderate RAU individuals developed
HKLM tolerance after four hours of stimulation; however in severe RAU patients HKLM tolerance was impaired [47].

The participation of TLR2 in the inflammatory process is not straightforward; various studies have shown that TLR2 stimulates the production of proinflammatory cytokines mediated by activation of NF- $\kappa \mathrm{B}$ in isolated cell types such as monocytes, dendritic cells, or PBMCs $[55,56]$.

The Discovery of $\mathrm{CD}^{+} \mathrm{CD} 25^{+}$regulatory $\mathrm{T}$ cells has improved understanding about controller mechanisms involved in the immune response. The activity of regulatory $\mathrm{T}$ cells is important for the inhibition of excessive inflammatory reactions, and this is dependent on TLR2 stimulation. TLR2 is expressed on the surface of regulatory T cells and can modulate the proliferation of those cells $[57,58]$. Thus, low activity of the TLR2 pathway may explain the lower number of $\mathrm{CD} 4{ }^{+} \mathrm{CD} 25^{+}$regulatory $\mathrm{T}$ cells found in the peripheral blood of patients with RAU and other Th1 inflammatory diseases [19, 59].

Because different types of cells are present at site of the inflammation in vivo, the final immune response will depend upon the balance between the dual TLR2 conflicting immune 
response. It is possible that impaired function of TLR2 would favor the production of an exaggerated inflammatory reaction mediated by the others TLR agonists present in that milieu. TLR2-deficient (TLR2-/ - ) mice develop more severe arthritis than wild type (TLR2+/+) mice. In (TLR2-/-) mice, the T cell balance in inflamed synovium tissue is shifted from Th2 and T regulatory cells toward pathogenic Th1 cells. In addition, the production of IFN- $\gamma$ by splenocytes is more pronounced in (TLR2-/-) knockout mice than in wild type mice [60] and (TLR2-/-) mice exhibit a preferential Th17 immunity that is associated with impaired expansion of regulatory CD4(+)CD25(+)FoxP3(+) T cells [61].

In normal individuals, the HSP60 enhances $\mathrm{CD} 4^{+} \mathrm{CD} 25^{+}$ $\mathrm{T}$ regulatory cell function via innate TLR2 signaling [62]. HSPs released by the cells after tissue injury can activate immune cell receptors and thus, based on the high degree of homology between microbial and human HSPs, act as signal danger, thereby triggering the development of a crossimmune reaction [63]. In RAU, it has been hypothesized that microbial HSP60, or HSP65, is responsible for the initiation of the cross-immune reaction against homologous host epithelial protein $[64,65]$. In susceptible patients, the release of HSP60 after oral trauma can stimulate secretion of proinflammatory cytokines [66], which is most likely due to abnormal TLR2 activity [47]. T cells and antibodies are often generated against host HSPs in healthy subjects and also as a response to autoimmune disorders. Nevertheless, the immune response to endogenous HSPs and microbial HSPs is not identical [63]. Host HSPs exhibit anti-inflammatory activity under certain conditions. HSP60, by stimulating TLR2, inhibits anti-CD3-induced IFN- $\gamma$ and TNF- $\alpha$ secretion and upregulates IL-10 secretion in freshly isolated human $\mathrm{T}$ cells [67]. T cells that have been isolated from the synovial fluid of patients with rheumatoid arthritis and stimulated with human HSP60 induce Th2 cytokines (e.g., IL-4, IL-10), whereas bacterial HSP60 induces IFN$\gamma$ (Th1) [68]. The exact mechanism of immune regulation is not known; however the possibility that HSP60 induces $\mathrm{CD} 4{ }^{+} \mathrm{CD} 25^{+}$regulatory T cells via TLR2 cannot be ignored [69].

2.4. The Importance of Epithelial Permeability for RAU. The behavior of TLR2-stimulated PBMCs may indicate that an imbalance in TLR-signaling pathways could be involved in the pathogenesis of RAU. This also suggests that a deficiency in TLR-signaling pathways may also occur in other types of cells, such as regulatory $\mathrm{T}$ cells and epithelial cells, whose TLR activity is important for immunological control and maintaining integrity of the epithelial barrier.

Stratified squamous epithelia, which are comprised of multiple layers of nonkeratinized or orthokeratinized cells connected by desmosomes, form a barrier to antigens in the oral cavity. The epithelial cells provide a permeability barrier to macromolecules, though small molecules and proteins can still diffuse into the cells. Regional variations in stratified squamous epithelia, such as variations in thickness, surface cell phenotypes, and protein expression, are determined both by genetic factors and by the local environment. The aphthous lesions are more prevalent in nonkeratinized regions of the oral cavity because it is likely that microtraumas facilitate penetration of antigens into the lamina propria where they stimulate reactive immune cells.

TLR2 participates in modulation of the epithelial barrier. Studies in the gut have shown that stimulation of TLR2 decreases mucosa permeability by increasing the function of the tight junctions. Deficient TLR2-signaling may cause an imbalance in the commensal-dependent epithelial-barrier protection, facilitate mucosal permeability, and lead to an increase in susceptibility to chronic mucosal inflammatory diseases. Similar to bowel diseases, this imbalance may also occur in RAU and create an increased susceptibility to chronic mucosal inflammatory diseases, mainly in nonkeratinized regions of the oral cavity. Notably, permeability mediated by TLR2 stimulation is capable of improving the outcomes of experimental colitis $[42,70,71]$.

Medications such as irsogladine that improve barrier protection by increasing the gap and tight junctions [72, 73] are effective in the prevention of RAU disease [7476]. Sucralfate is a locally acting substance that attaches to proteins on the surface of mucosa to form a stable, insoluble complex that can diminish epithelial permeability [77]. In clinical studies, the use of sucralfate for two years was effective in reducing the healing period, pain, and duration of remission of the cases with aphthous lesions. This medication is as effective for prevention as it is for epithelial regeneration after injury [78]. Rebamipide, another antiulcer agent, improves aphthous lesions and pain in patients with Behçet's disease [79]. This medication protects the gastric mucosa and decreases the permeability of the epithelial barrier by acting as a radical scavenger and decreasing production of proinflammatory mediators [80]. In contrast, substances that increase epithelial permeability could act as facilitator agents for disease-onset. Studies have provided evidence of the relationship between use of toothpastes containing sodium lauryl sulphate and an increase in the prevalence of RAU [81, 82]. Depending on the dose, sodium lauryl sulphate is able to break down the epithelial barrier and increase permeability $[83,84]$.

On the other hand, mucosal resident intraepithelial and interstitial dendritic cells, found throughout the entire oral epithelium and lamina propria, participate in the immune response by inducing tolerance to food or commensal bacteria and by inducing a reaction against harmful pathogens. Interstitial dendritic cells (FXIIIa+) are frequently found within the mononuclear infiltrated area and in the perivascular areas of RAU lesions [85]. The highest density of dendritic cells is found in the same area affected by RAU disease, in the nonkeratinized mucosa of the soft palate, ventral tongue, lip, and vestibule, most likely because of higher antigen exposure, while the lowest density of dendritic cells is found in the keratinized mucosa of the hard palate and gingiva [52, 86, 87]. Mucosal epithelial dendritic cells are immature and thus are inefficient at stimulating $\mathrm{T}$ cells. Immature DCs capture and process antigen, express low levels of MHC and costimulatory molecules, and produce high levels of IL-10. However, contact of TLRs with antigens 
from microbes induces the maturation process, which upregulates expression of costimulator receptors and induces the migration of DCs into the secondary lymphoid organ of the oral cavity (oral lymphoid foci or lymph nodes).

Additionally, in RAU, the presence of lymphocytes bearing the $\mathrm{T}$ cell receptor $\gamma \delta$ (gamma delta) in the oral mucosa seems to play a key role in the immune-pathogenesis of the disease. The proportion of $\gamma \delta \mathrm{T}$ lymphocytes in mucosal and peripheral blood from RAU patients is higher than controls, and after stimulation, these cells preferentially secrete IFN- $\gamma$ and TNF- $\alpha[88,89]$. It was discovered that $\gamma \delta \mathrm{T}$ cells are an important source of IL-17, which is considered a key cytokine for sustaining the inflammatory response [90]. T lymphocytes bearing the $\gamma \delta$ receptor have been implicated in the host defense against microbial agents and in the response to inflammatory challenges [91]. On the other side, it was recently found that $\gamma \delta \mathrm{T}$ is able to terminate inflammation and to facilitate recovery from infections by inducing a cytotoxic reaction against activated inflammatory cells that express HSPs on the surface [92]. In addition, $\gamma \delta \mathrm{T}$ cells are involved on epithelial homeostasis by production of growth factors [93]. The balance of proand anti-inflammatory activity of $\gamma \delta \mathrm{T}$ cells appears to be significant for limiting the inflammatory processes and preventing host tissue damage. Mice depleted of $\gamma \delta \mathrm{T}$ cells develop more severe colitis in a model of inflammatory bowel disease probably in function of the a deficiency on control of IFN- $\gamma$ and epithelial regeneration [94]. There are evidences that show that $\mathrm{CD} 4{ }^{+} \mathrm{CD} 25^{+}$inhibits the proliferation of $\gamma \delta \mathrm{T}$ cells [95] and consequently the low number of $\mathrm{CD} 4{ }^{+} \mathrm{CD} 25^{+}$observed in RAU could influence the elevated numbers of $\gamma \delta \mathrm{T}$ cells found in their mucosa and peripheral blood.

\section{Connections between Predisposing Factors and RAU}

3.1. The Effect of Smoking on RAU. Cigarette smoking is considered a protective factor for RAU [2]. The prevalence of RAU in smokers is lower than that in nonsmoking persons. Moreover, the prevalence of RAU increases after smoking cessation but can be reversed after nicotine replacement therapy [96]. It has been proposed that the increase in oral keratinization associated with tobacco use could explain this protection; however the participation of other factors, such as immune modulation and stress repression should not be discounted. Cessation of smoking often affects the endocrine system in the short-term and induces a decrease in the level of cortisol and adrenocortical responses to stress [97], which could cause an imbalanced immune reaction. Although evidence regarding the effects of cigarette-smoking toxins and nicotine on the Th1/Th2 balance is inconclusive, some studies have shown that the peripheral IFN- $\gamma /$ IL10 (Th1/Th2) ratio is lower in smokers compared to nonsmokers [32]. Cultured whole blood cells of smoking had a lower IL-12 p40/IL-10 ratio and produced less IL1$\beta$ than nonsmokers [33]. In another study, nicotine caused a significant inhibition of IL- 2 and TNF- $\alpha$ production in mononuclear cells from healthy volunteers [34].
In addition, smoking is capable of enhancing the expression and modifying the distribution of heat shock protein 27 (HSP27) in oral epithelial cells. HSP27 exerts antiapoptotic and anti-inflammatory effects by blocking activation of the nuclear transcription factor $\mathrm{NF}-\kappa \mathrm{B}$ and the mitogen protein kinase (MAPK) pathways and by inducing the secretion of IL-10 [17]. Additionally, small HSPs may act to stabilize cellto-cell contact and maintain the integrity of the epithelial barrier against bacteria and their toxic by-products [98]. Thus, the lower expression of the HSP27 protein seen in RAU patients [17] may help to explain the beneficial effect of smoking on RAU outcomes.

3.2. The Effect of Stress on RAU. During an inflammatory response, the activation of the stress system through induction of a Th2 shift may offer protection for systemic "overshooting" with Th1 lymphocyte/proinflammatory cytokines. However, under certain conditions, stress hormones may actually facilitate inflammation through induction of IL1, IL-6, IL-8, IL-18, TNF- $\alpha$, and corticotropin-releasing hormone production [20]. In students who were reactors to psychological stress, a reduction in the CD4(+)/CD8 $(+) \mathrm{T}$ cell ratio [99] and an increase in IFN- $\gamma$, TNF- $\alpha$, IL-10 levels, and the IFN- $\gamma /$ IL- 5 ratio were observed after stress induced by academic examinations [21].

In patients who are suffering from psoriasis (Th1 disease), the reactivity of the sympathetic adrenomedullary system to stress is heightened compared to people without the disease. These patients have elevated epinephrine and norepinephrine levels in response to a stress test when compared to the controls [100]. Furthermore, it was shown that stimulation of PBMCs isolated from patients with psoriasis results in elevated production of IFN- $\gamma$ and IL-2 and low production of IL-10 and IL-4 [22]. PBMCs from patients with rheumatoid arthritis (Th1 disease) show a preferential inhibitory effect of catecholamines on IFN- $\gamma$ production and a failure to induce a shift of T-cell cytokine responses toward a Th2 immune response [23].

The beta2-adrenergic receptor (beta2-AR) subtype is expressed exclusively by $\mathrm{T}$ and $\mathrm{B}$ lymphocytes. Expression of the beta2-adrenergic receptor is maintained when naive $\mathrm{T}$ cells are differentiated into Th1 cells, but expression is repressed when naive $\mathrm{T}$ cells are differentiated into Th2 cells. The alpha1-, alpha2-, and beta2-adrenergic receptors are found in macrophages, and when treated with norepinephrine, they are able to inhibit TNF- $\alpha$ production induced by LPS treatment [101]. Stimulation of beta2ARs with norepinephrine in immune cells inhibits the Th1 immune response, and the obstruction of beta1- and beta2ARs with beta-blockers causes Th1 polarization, which, in turn, enhances the local expression of IFN- $\gamma$, IL-12, and IL23 [28]; this process may explain the relationship between beta-blocker drugs and the development of RAU symptoms.

There is also cross-regulation between the immune and endocrine system, and TLRs may play a key role in this process. TLR2 and TLR4, stimulated with Pam3CSK4 and LPS, respectively, are able to directly mediate the increase of corticosterone secretion in human adrenal cells [102]. TLR-2-deficient mice have impaired adrenal corticosterone 
release after inflammatory stress induced by a bacterial cell wall compound [103].

\subsection{The Effect of Vitamin Deficiency on RAU. Vitamin B12} appears to be effective for patients suffering from RAU by decreasing the number of crises or the time of suffering regardless of the serum cobalamin (B12 vitamin) levels [104, 105]. Cobalamin and B6 serum concentrations appear to be indirectly correlated with the synthesis and release of TNF- $\alpha[30,31]$ whose levels are normalized with respect to B12 vitamin reposition [30]. Elevated levels of total homocysteine are an accurate marker for impaired folate metabolism that may result from insufficient dietary intake of folates or vitamins B12, B6, or B2 [106]. The higher levels of homocysteine in patients with RAU and Behçet's disease compared to healthy individuals may indicate the existence of deficient folate metabolism in some patients, which could in turn facilitate the Th1 immune reaction [107]. In addition, a nutritional deficiency, such as that of zinc, folic acid, or vitamins $\mathrm{A}$ and $\mathrm{D}$ can facilitate destruction of the epithelial barrier and expose the body to foreign materials, such as proteins, microorganisms, and toxins [108].

3.4. The Effect of Food and Breast Feeding History on RAU. A considerable number of RAU patients report an onset of crisis after consuming pineapple. This fruit is rich in bromelain, a protein that is associated with an increase in production of the Th1 cytokines TNF- $\alpha$ and IFN- $\gamma$ but not with Th2 cytokines IL-4 and IL-5 [26]. Furthermore, bromelain enhances the permeability of the mucosa and increases the absorption of exogenous antigens [27]. The influence of bromelain on epithelial permeability and on the Th1 immune reaction may explain, in certain groups of patients, the relationship between pineapple consumption and RAU-onset.

Recently the breast feeding history was negatively associated with RAU [2]. Epidemiologic studies have indicated that breast feeding protects the infant against chronic diseases later in life. Human milk contains many components (i.e., TGF- $\beta$ and IL-10) that promote tolerance to the dietary and microflora antigens. In addition, the breast feeding is capable of increasing the levels of natural regulatory $\mathrm{T}$ cells [36]. In some population, the breast feeding is considered a protective factor for Crohn's Disease development [109].

3.5. Proposing a Model for RAU Disease. Based on this review we propose a rational model for RAU that could be useful for diagnosis and treatment decisions. Like other gastrointestinal chronic inflammatory diseases, patients with RAU possess a predisposed imbalance of Th1/Th2 immune response and also a possibly epithelial barrier dysfunction of the oral mucosa caused by a lack of activity of the TLR2 pathway, which are most likely a function of their genetic background (Figure 1, (A) and (C)). The polarization of the immune response in RAU can be enhanced by conditions that drive the reaction into the direction of Th1 such as stress, NSAIDs, bromelain [26, 27], $\beta$-blockers, imiquimod [29], or hypovitaminosis (Figure 1(B) and Table 1). On the other hand, factors that are often associated with RAU, such as the consumption of pineapple, which is rich in proteases like bromelain [27]; toothpastes containing sodium lauryl sulfate $[82,84]$; or nutritional deficiencies that affect zinc, acid folic, or vitamin A or D levels [108] are able to increase mucosal permeability (Figure $1(\mathrm{C})$ ). This facilitates contact of immune competent cells from the lamina propria with oral antigens or with released host proteins in a milieu rich in Th1 cytokines, and this likely influences the onset and outcome of RAU.

When patients are exposed to conditions or treatments that increase Th2 or $\mathrm{T}$ regulatory response like cigarette smoking, pregnancy, breast feeding, thalidomide, or TNF inhibitors (Table 1), the Th1/Th2 imbalance is restored and the disease can be controlled (Figure 1(D)). Additionally, when patients are submitted to topical or antiulcer medications (sucralfate, rebamipide, and irsogladine) [72, 73, $77,80]$ or situations (smoking) that diminish mucosal permeability, the onset of RAU can also be prevented (Figure 1(E)).

In addition, this disease requires a reduction of immune tolerance. The activity of regulatory T cells like $\mathrm{CD} 4^{+} \mathrm{CD} 25^{+}$ and of IL-10 and TGF- $\beta$ anti-inflammatory cytokines can regulate the onset and outcome of the inflammatory reaction by inhibiting both Th1 and Th2 immune reactions. According to the hygiene hypothesis, the contact with some microorganisms in early childhood is important for development of regulatory mechanisms of the immune system in such a way that a reduction in the incidence of infectious diseases is associated with aberrant immune responses in the setting of chronic inflammatory diseases [110]. The breast feeding is another important factor responsible for the increase of the immune tolerance [36] (Figure $1(\mathrm{G})$ ). Patients with lowered tolerance are more susceptible to chronic inflammatory diseases, and in RAU, this low tolerance $[19,47,59]$ could favor the onset of the disease in a situation where normal individuals are resistant (Figure 1(F)). The participation of the Th17 subset in this model is unclear but could act by diminishing immune tolerance since the development of the Th17 and regulatory $\mathrm{t}$ cells seems to be mutually exclusive (Figure $1(\mathrm{G})$ ).

The combinations of factors described in this hypothesis vary across different types of RAU patients. The existence of Th1 polarization and/or the low-tolerance state in other Th1 diseases like celiac disease, Behçet, or Crohn's disease favors the manifestation of aphthous-like lesions in the oral mucosa of patients with these diseases.

Research has shown that employment of prebiotics or probiotics can control the onset and outcomes of numerous Th1/Th2 diseases. In addition, evidence indicates that probiotic bacteria stimulate intestinal epithelial cell responses including restoration of injured epithelial barriers, production of antibacterial substances and cell-protective proteins, and blockade of cytokine-induced intestinal epithelial cell apoptosis [111], which could be beneficial for maintaining homeostasis of the oral mucosa. Based on proposal model, we speculated that the use of probiotics could stimulate the development of regulatory $\mathrm{T}$ cells and the augment of the epithelial barrier, in order to control the onset 


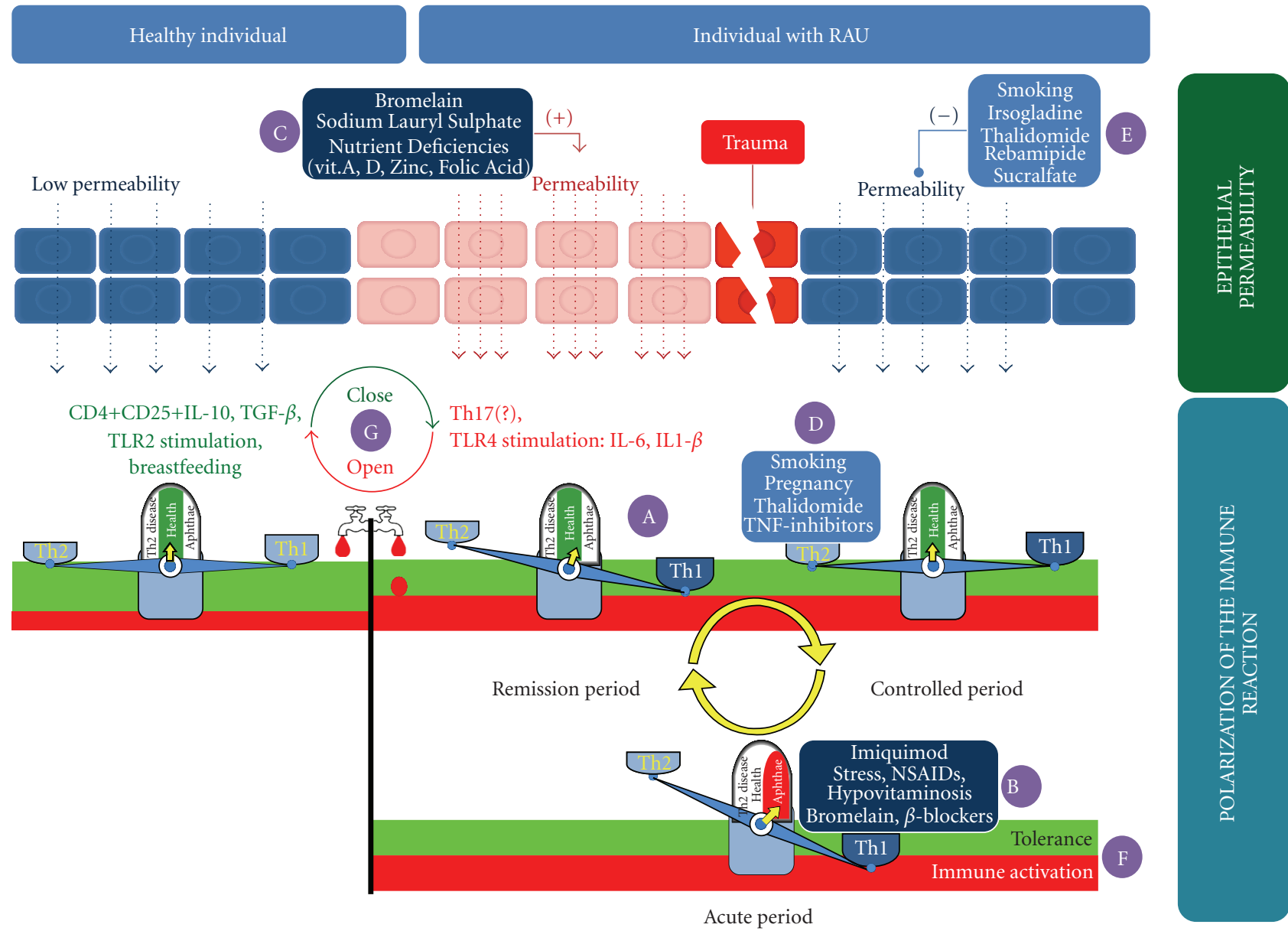

Figure 1: The Disease Model of RAU. The genetic background of RAU carriers favors Th1 polarization of the immune reaction (A). A combination of endogenous and exogenous factors that enhances the Th1/Th2 imbalance (B) and augments permeability of the oral mucosa (C) facilitates contact of immune competent cells from the lamina propria with oral antigens or with released host proteins in a milieu rich in Th1 cytokines; this likely influences the onset and outcome of RAU. Conditions that enhance the Th2 immune response (D), diminish epithelium permeability (E), or augment peripheral tolerance (F and G), such as IL-10, TGF- $\beta$, and CD4 $4^{+} \mathrm{CD} 25^{+}$, may counteract Th1/Th2 disruption, thus aiding in either the prevention of RAU onset or ameliorating its outcomes. The production of $\mathrm{CD} 4^{+} \mathrm{CD} 25^{+}$cells is probably inversely proportional to Th17 cells (G), which could potentially influence the induction and maintenance of the inflammatory reaction.

and outcome of the RAU for a major period of time without the side effects caused by usual anti-inflammatory treatments.

\section{Final Conclusions}

RAU is considered a multifactorial oral ulcerative disease that preferentially affects nonkeratinized mucosa from predisposed individuals whose genetic background favors an imbalance of the Th1/Th2 immune reaction with a consequent decrease in peripheral tolerance. It is likely that lack of TLR2 activity affects the regulatory function of the immune system and epithelial permeability, and this favors the development of a local inflammatory reaction mediated by the diverse types of stimuli. The weakening of epithelial cells facilitates penetration of oral antigens that maintain a pool of preactivated professional presentation cells, $\gamma \delta \mathrm{T}$ cells, among others, which induces a cellular cytotoxic immune reaction against local epithelial cells.

\section{Competing Interests}

The authors declare that they have no competing interests.
Abbreviations
RAU: $\quad$ Recurrent Aphthous Ulceration
NSAIDs: Non steroidal anti-inflammatory drugs
TLR: Toll-like receptors
PBMC: Peripheral blood mononuclear cells
PAMPs: Pathogen-associated molecular patterns
LTA: Lipoteichoic acid
DCs: Dendritic cells
HKLM: Heat-killed Listeria monocytogenes
MAPK: Mitogen protein kinase. 


\section{Acknowledgments}

This work has been funded by Grants from Fundo de Amparo à Pesquisa do Estado de São Paulo (FAPESP) Grant no. 05/59738-2 and Conselho Nacional de Desenvolvimento Científico e Tecnológico (CNPq) Grant no. 471639/20079. Any opinions, findings, and conclusions or recommendations expressed in this article are those of the author(s) and do not necessarily reflect the views of the sponsors. The funding body played no role in study design; in the collection, analysis, and interpretation of data; in the writing of the manuscript; and in the decision to submit the manuscript for publication.

\section{References}

[1] C. Scully and S. Porter, "Oral mucosal disease: recurrent aphthous stomatitis," The British Journal of Oral and Maxillofacial Surgery, vol. 46, no. 3, pp. 198-206, 2008.

[2] M. J. McCullough, S. Abdel-Hafeth, and C. Scully, "Recurrent aphthous stomatitis revisited; clinical features, associations, and new association with infant feeding practices?" Journal of Oral Pathology and Medicine, vol. 36, no. 10, pp. 615-620, 2007.

[3] R. I. E. Lake, S. J. Thomas, and N. G. Martin, "Genetic factors in the aetiology of mouth ulcers," Genetic Epidemiology, vol. 14, no. 1, pp. 17-33, 1997.

[4] A. L. S. Guimaraes, J. d. F. Correia-Silva, A. R. Sa, et al., "Investigation of functional gene polymorphisms IL- $1 \beta$, IL6 , IL-10 and TNF- $\alpha$ in individuals with recurrent aphthous stomatitis," Archives of Oral Biology, vol. 52, no. 3, pp. 268272, 2007.

[5] M. R. Bazrafshani, A. H. Hajeer, W. E. R. Ollier, and M. H. Thornhill, "IL-1B and IL-6 gene polymorphisms encode significant risk for the development of recurrent aphthous stomatitis (RAS)," Genes and Immunity, vol. 3, no. 5, pp. 302305, 2002.

[6] J. M. N. Victoria, J. D. F. Correia-Silva, F. J. Pimenta, E. Kalapothakis, and R. S. Gomez, "Serotonin transporter gene polymorphism (5-HTTLPR) in patients with recurrent aphthous stomatitis," Journal of Oral Pathology and Medicine, vol. 34, no. 8, pp. 494-497, 2005.

[7] R. Shohat-Zabarski, S. Kalderon, T. Klein, and A. Weinberger, "Close association of HLA-B51 in persons with recurrent aphthous stomatitis," Oral Surgery Oral Medicine and Oral Pathology, vol. 74, no. 4, pp. 455-458, 1992.

[8] A. Weinberger, "Human lymphocyte antigen (HLA) B51 is more frequent in patients with recurrent aphthous stomatitis (RAS)," Clinical and Experimental Rheumatology, vol. 15, no. 1, pp. 118-119, 1997.

[9] L. Jaber, A. Weinberger, T. Klein, I. Yaniv, and M. Mukamel, "Close association of HLA-B52 and HLA-B44 antigens in Israeli Arab adolescents with recurrent aphthous stomatitis," Archives of Otolaryngology-Head \& Neck Surgery, vol. 127, no. 2, pp. 184-187, 2001.

[10] R. C. Borra, P. M. Andrade, I. D. Silva, et al., “The Th1/Th2 immune-type response of the recurrent aphthous ulceration analyzed by cDNA microarray," Journal of Oral Pathology and Medicine, vol. 33, no. 3, pp. 140-146, 2004.

[11] J. Freysdottir, S. Zhang, W. M. Tilakaratne, and F. Fortune, "Oral biopsies from patients with orofacial granulomatosis with histology resembling Crohn's disease have a prominent
Th1 environment," Inflammatory Bowel Diseases, vol. 13, no. 4, pp. 439-445, 2007.

[12] P. Garside, A. Mc. I. Mowat, and A. Khoruts, "Oral tolerance in disease," Gut, vol. 44, no. 1, pp. 137-142, 1999.

[13] A. K. Chakrabarty, S. Mraz, J. K. Geisse, and N. J. Anderson, "Aphthous ulcers associated with imiquimod and the treatment of actinic cheilitis," Journal of the American Academy of Dermatology, vol. 52, no. 2, supplement 1, pp. S35-S37, 2005.

[14] I. Zalaudek, G. Petrillo, and G. Argenziano, "Aphthous ulcers and imiquimod," Journal of the American Academy of Dermatology, vol. 53, no. 2, pp. 360-361, 2005.

[15] I. Monteleone, F. Pallone, and G. Monteleone, "Interleukin23 and Th17 cells in the control of gut inflammation," Mediators of Inflammation, vol. 2009, Article ID 297645, 7 pages, 2009.

[16] E. Albanidou-Farmaki, A. K. Markopoulos, F. Kalogerakou, and D. Z. Antoniades, "Detection, enumeration and characterization of $\mathrm{T}$ helper cells secreting type 1 and type 2 cytokines in patients with recurrent aphthous stomatitis," Tohoku Journal of Experimental Medicine, vol. 212, no. 2, pp. 101-105, 2007.

[17] N. T. Miyamoto Jr., R. C. Borra, M. Abreu, L. L. M. Weckx, and M. Franco, "Immune-expression of HSP27 and IL-10 in recurrent aphthous ulceration," Journal of Oral Pathology and Medicine, vol. 37, no. 8, pp. 462-467, 2008.

[18] I. J. Buno, J. C. Huff, W. L. Weston, D. T. Cook, and S. L. Brice, "Elevated levels of interferon gamma, tumor necrosis factor $\alpha$, interleukins 2,4 , and 5 , but not interleukin 10 , are present in recurrent aphthous stomatitis," Archives of Dermatology, vol. 134, no. 7, pp. 827-831, 1998.

[19] N. Lewkowicz, P. Lewkowicz, M. Banasik, A. Kurnatowska, and H. Tchorzewski, "Predominance of type 1 cytokines and decreased number of $\mathrm{CD} 4^{+} \mathrm{CD} 25^{\text {thigh }} \mathrm{T}$ regulatory cells in peripheral blood of patients with recurrent aphthous ulcerations," Immunology Letters, vol. 99, no. 1, pp. 57-62, 2005.

[20] E. Calcagni and I. Elenkov, "Stress system activity, innate and $\mathrm{T}$ helper cytokines, and susceptibility to immune-related diseases," Annals of the New York Academy of Sciences, vol. 1069, pp. 62-76, 2006.

[21] M. Maes, A. Christophe, E. Bosmans, A. Lin, and H. Neels, "In humans, serum polyunsaturated fatty acid levels predict the response of proinflammatory cytokines to psychologic stress," Biological Psychiatry, vol. 47, no. 10, pp. 910-920, 2000.

[22] A. Buske-Kirschbaum, S. Kern, M. Ebrecht, and D. H. Hellhammer, "Altered distribution of leukocyte subsets and cytokine production in response to acute psychosocial stress in patients with psoriasis vulgaris," Brain, Behavior, and Immunity, vol. 21, no. 1, pp. 92-99, 2007.

[23] M. Wahle, G. Hanefeld, S. Brunn, et al., "Failure of catecholamines to shift T-cell cytokine responses toward a Th2 profile in patients with rheumatoid arthritis," Arthritis Research and Therapy, vol. 8, no. 5, article R138, 2006.

[24] D. E. Griswold, L. M. Hillegass, J. J. Breton, K. M. Esser, and J. L. Adams, "Differentiation in vivo of classical nonsteroidal antiinflammatory drugs from cytokine suppressive antiinflammatory drugs and other pharmacological classes using mouse tumour necrosis factor alpha production," Drugs under Experimental and Clinical Research, vol. 19, no. 6, pp. 243-248, 1993.

[25] I. Tsuboi, H. Tanaka, M. Nakao, S. Shichijo, and K. Itoh, "Nonsteroidal anti-inflammatory drugs differentially regulate cytokine production in human lymphocytes: 
up-regulation of TNF, IFN-gamma and IL-2, in contrast to down-regulation of IL-6 production," Cytokine, vol. 7, no. 4, pp. 372-379, 1995.

[26] H. Barth, A. Guseo, and R. Klein, "In vitro study on the immunological effect of bromelain and trypsin on mononuclear cells from humans," European Journal of Medical Research, vol. 10, no. 8, pp. 325-331, 2005.

[27] D. Guggi and A. Bernkop-Schnurch, "Improved paracellular uptake by the combination of different types of permeation enhancers," International Journal of Pharmaceutics, vol. 288, no. 1, pp. 141-150, 2005.

[28] M. Manni and G. J. M. Maestroni, "Sympathetic nervous modulation of the skin innate and adaptive immune response to peptidoglycan but not lipopolysaccharide: involvement of $\beta$-adrenoceptors and relevance in inflammatory diseases," Brain, Behavior, and Immunity, vol. 22, no. 1, pp. 80-88, 2008.

[29] F. Lacarrubba, M. R. Nasca, and G. Micali, "Advances in the use of topical imiquimod to treat dermatologic disorders," Therapeutics and Clinical Risk Management, vol. 4, no. 1, pp. 87-97, 2008.

[30] M. Peracchi, F. Bamonti Catena, M. Pomati, M. De Franceschi, and G. Scalabrino, "Human cobalamin deficiency: alterations in serum tumour necrosis factor- $\alpha$ and epidermal growth factor," European Journal of Haematology, vol. 67, no. 2, pp. 123-127, 2001.

[31] R. Roubenoff, R. A. Roubenoff, J. Selhub, et al., "Abnormal vitamin B6 status in rheumatoid cachexia. Association with spontaneous tumor necrosis factor alpha production and markers of inflammation," Arthritis and Rheumatism, vol. 38, no. 1, pp. 105-109, 1995.

[32] C. A. Whetzel, E. J. Corwin, and L. C. Klein, "Disruption in Th1/Th2 immune response in young adult smokers," Addictive Behaviors, vol. 32, no. 1, pp. 1-8, 2007.

[33] G. L. Torres de Heens, R. Kikkert, L. A. Aarden, U. van der Velden, and B. G. Loos, "Effects of smoking on the ex vivo cytokine production in periodontitis," Journal of Periodontal Research, vol. 44, no. 1, pp. 28-34, 2009.

[34] G. S. Madretsma, G. J. Donze, A. P. M. van Dijk, C. J. Tak, J. H. P. Wilson, and F. J. Zijlstra, "Nicotine inhibits the in vitro production of interleukin 2 and tumour necrosis factor$\alpha$ by human mononuclear cells," Immunopharmacology, vol. 35, no. 1, pp. 47-51, 1996.

[35] J. R. Challis, C. J. Lockwood, L. Myatt, J. E. Norman, J. F. Strauss III, and F. Petraglia, "Inflammation and pregnancy," Reproductive Sciences, vol. 16, no. 2, pp. 206-215, 2009.

[36] S. Brugman, J. T. J. Visser, J. L. Hillebrands, N. A. Bos, and J. Rozing, "Prolonged exclusive breastfeeding reduces autoimmune diabetes incidence and increases regulatory Tcell frequency in bio-breeding diabetes-prone rats," Diabetes/Metabolism Research and Reviews, vol. 25, no. 4, pp. 380-387, 2009.

[37] L. G. Corral, P. A. J. Haslett, G. W. Muller, et al., "Differential cytokine modulation and $\mathrm{T}$ cell activation by two distinct classes of thalidomide analogues that are potent inhibitors of TNF-alpha," International Journal of Leprosy and Other Mycobacterial Diseases, vol. 163, no. 1, pp. 380-386, 1999.

[38] D. R. Moller, M. Wysocka, B. M. Greenlee, et al., "Inhibition of IL-12 production by thalidomide," Journal of Immunology, vol. 159, no. 10, pp. 5157-5161, 1997.

[39] I. Ricciardelli, K. J. Lindley, M. Londei, and S. Quaratino, "Anti tumour necrosis- $\alpha$ therapy increases the number of FOXP3 + regulatory T cells in children affected by Crohn's disease," Immunology, vol. 125, no. 2, pp. 178-183, 2008.
[40] E. Toubi, A. Kessel, Z. Mahmudov, K. Hallas, M. Rozenbaum, and I. Rosner, "Increased spontaneous apoptosis of $\mathrm{CD} 4{ }^{+} \mathrm{CD} 25^{+} \mathrm{T}$ cells in patients with active rheumatoid arthritis is reduced by infliximab," Annals of the New York Academy of Sciences, vol. 1051, pp. 506-514, 2005.

[41] J. Bienvenu, C. Doche, M.-C. Gutowski, M. Lenoble, A. Lepape, and J.-P. Perdrix, "Production of proinflammatory cytokines and cytokines involved in the TH1/TH2 balance is modulated by pentoxifylline," Journal of Cardiovascular Pharmacology, vol. 25, supplement 2, pp. S80-S84, 1995.

[42] E. Cario, "Barrier-protective function of intestinal epithelial Toll-like receptor 2," Mucosal Immunology, vol. 1, supplement 1, pp. S62-S66, 2008.

[43] J. A. Ship, E. M. Chavez, P. A. Doerr, B. S. Henson, and M. Sarmadi, "Recurrent aphthous stomatitis," Quintessence International, vol. 31, no. 2, pp. 95-112, 2000.

[44] A. Jacobi, D. Debus, G. Schuler, and M. Hertl, "Infliximab in a patient with refractory mucosal aphthosis," Journal of the European Academy of Dermatology and Venereology, vol. 22, no. 1, pp. 109-110, 2008.

[45] N. D. Robinson and J. Guitart, "Recalcitrant, recurrent aphthous stomatitis treated with etanercept," Archives of Dermatology, vol. 139, no. 10, pp. 1259-1262, 2003.

[46] D. Sanchez-Cano, J. L. Callejas-Rubio, R. Ruiz-Villaverde, and N. Ortego-Centeno, "Recalcitrant, recurrent aphthous stomatitis successfully treated with adalimumab," Journal of the European Academy of Dermatology and Venereology, vol. 23, no. 2, article 206, 2009.

[47] R. C. Borra, F. de Mesquita Barros, M. de Andrade Lotufo, F. E. Villanova, and P. M. Andrade, "Toll-like receptor activity in recurrent aphthous ulceration," Journal of Oral Pathology and Medicine, vol. 38, no. 3, pp. 289-298, 2009.

[48] K. Takeda and S. Akira, "Toll-like receptors in innate immunity," International Immunology, vol. 17, no. 1, pp. 1$14,2005$.

[49] H. Qi, T. L. Denning, and L. Soong, "Differential induction of interleukin-10 and interleukin-12 in dendritic cells by microbial Toll-like receptor activators and skewing of T-cell cytokine profiles," Infection and Immunity, vol. 71, no. 6, pp. 3337-3342, 2003.

[50] F. Re and J. L. Strominger, "IL-10 released by concomitant TLR2 stimulation blocks the induction of a subset of Th1 cytokines that are specifically induced by TLR4 or TLR3 in human dendritic cells," Journal of Immunology, vol. 173, no. 12, pp. 7548-7555, 2004.

[51] S. Dillon, A. Agrawal, T. Van Dyke, et al., "A Toll-like receptor 2 ligand stimulates Th2 responses in vivo, via induction of extracellular signal-regulated kinase mitogenactivated protein kinase and c-Fos in dendritic cells," Journal of Immunology, vol. 172, no. 8, pp. 4733-4743, 2004.

[52] N. Novak, J. Haberstok, T. Bieber, and J.-P. Allam, "The immune privilege of the oral mucosa," Trends in Molecular Medicine, vol. 14, no. 5, pp. 191-198, 2008.

[53] M. Palazzo, S. Gariboldi, L. Zanobbio, et al., "Cross-talk among Toll-like receptors and their ligands," International Immunology, vol. 20, no. 5, pp. 709-718, 2008.

[54] M. G. Netea, B. J. Kullberg, D. J. de Jong, et al., "NOD2 mediates anti-inflammatory signals induced by TLR2 ligands: implications for Crohn's disease," European Journal of Immunology, vol. 34, no. 7, pp. 2052-2059, 2004.

[55] T. K. Ghosh, D. J. Mickelson, J. C. Solberg, K. E. Lipson, J. R. Inglefield, and S. S. Alkan, "TLR-TLR cross talk in human PBMC resulting in synergistic and antagonistic regulation of 
type- 1 and 2 interferons, IL-12 and TNF- $\alpha$," International Immunopharmacology, vol. 7, no. 8, pp. 1111-1121, 2007.

[56] R. J. Dearman, M. Cumberbatch, G. Maxwell, D. A. Basketter, and I. Kimber, "Toll-like receptor ligand activation of murine bone marrow-derived dendritic cells," Immunology, vol. 126, no. 4, pp. 475-484, 2009.

[57] R. P. M. Sutmuller, M. H. den Brok, M. Kramer, et al., "Tolllike receptor 2 controls expansion and function of regulatory T cells," Journal of Clinical Investigation, vol. 116, no. 2, pp. 485-494, 2006.

[58] H. Liu, M. Komai-Koma, D. Xu, and F. Y. Liew, “Toll-like receptor 2 signaling modulates the functions of $\mathrm{CD} 4{ }^{+} \mathrm{CD} 25^{+}$ regulatory T cells," Proceedings of the National Academy of Sciences of the United States of America, vol. 103, no. 18, pp. 7048-7053, 2006.

[59] N. Lewkowicz, P. Lewkowicz, K. Dzitko, et al., "Dysfunction of $\mathrm{CD} 4{ }^{+} \mathrm{CD} 25^{\text {high }} \mathrm{T}$ regulatory cells in patients with recurrent aphthous stomatitis," Journal of Oral Pathology and Medicine, vol. 37, no. 8, pp. 454-461, 2008.

[60] S. Abdollahi-Roodsaz, L. A. B. Joosten, M. I. Koenders, et al., "Stimulation of TLR2 and TLR4 differentially skews the balance of T cells in a mouse model of arthritis," Journal of Clinical Investigation, vol. 118, no. 1, pp. 205-216, 2008.

[61] F. V. Loures, A. Pina, M. Felonato, and V. L. Calich, "TLR2 is a negative regulator of Th17 cells and tissue pathology in a pulmonary model of fungal infection," Journal of Immunology, vol. 183, no. 2, pp. 1279-1290, 2009.

[62] A. Zanin-Zhorov, L. Cahalon, G. Tal, R. Margalit, O. Lider, and I. R. Cohen, "Heat shock protein 60 enhances $\mathrm{CD} 4{ }^{+} \mathrm{CD} 25^{+}$regulatory $\mathrm{T}$ cell function via innate TLR2 signaling," Journal of Clinical Investigation, vol. 116, no. 7, pp. 2022-2032, 2006.

[63] A. G. Pockley, M. Muthana, and S. K. Calderwood, "The dual immunoregulatory roles of stress proteins," Trends in Biochemical Sciences, vol. 33, no. 2, pp. 71-79, 2008.

[64] A. Hasan, T. Shinnick, Y. Mizushima, R. van der Zee, and T. Lehner, "Defining a T-cell epitope within HSP 65 in recurrent aphthous stomatitis," Clinical and Experimental Immunology, vol. 128, no. 2, pp. 318-325, 2002.

[65] A. Hasan, A. Childerstone, K. Pervin, et al., "Recognition of a unique peptide epitope of the mycobacterial and human heat shock protein 65-60 antigen by T cells of patients with recurrent oral ulcers," Clinical and Experimental Immunology, vol. 99, no. 3, pp. 392-397, 1995.

[66] C. Habich and V. Burkart, "Heat shock protein 60: regulatory role on innate immune cells," Cellular and Molecular Life Sciences, vol. 64, no. 6, pp. 742-751, 2007.

[67] A. Zanin-Zhorov, R. Bruck, G. Tal, et al., "Heat shock protein 60 inhibits Th1-mediated hepatitis model via innate regulation of Th1/Th2 transcription factors and cytokines," Journal of Immunology, vol. 174, no. 6, pp. 3227-3236, 2005.

[68] J. A. G. van Roon, W. van Eden, J. L. van Roy, F. J. Lafeber, and J. W. J. Bijlsma, "Stimulation of suppressive T cell responses by human but not bacterial $60-\mathrm{kD}$ heat-shock protein in synovial fluid of patients with rheumatoid arthritis," Journal of Clinical Investigation, vol. 100, no. 2, pp. 459-463, 1997.

[69] F. J. Quintana, A. Mimran, P. Carmi, F. Mor, and I. R. Cohen, "HSP60 as a target of anti-ergotypic regulatory T cells," PLoS One, vol. 3, no. 12, article e4026, 2008.

[70] E. Cario, G. Gerken, and D. K. Podolsky, "Toll-like receptor 2 enhances ZO-1-associated intestinal epithelial barrier integrity via protein kinase C," Gastroenterology, vol. 127, no. 1, pp. 224-238, 2004.
[71] J. Chen, J. N. Rao, T. Zou, et al., "Polyamines are required for expression of Toll-like receptor 2 modulating intestinal epithelial barrier integrity," American Journal of Physiology, vol. 293, no. 3, pp. G568-G576, 2007.

[72] Y. Uchida, H. Shiba, H. Komatsuzawa, et al., "Irsogladine maleate influences the response of gap junctional intercellular communication and IL-8 of human gingival epithelial cells following periodontopathogenic bacterial challenge," Biochemical and Biophysical Research Communications, vol. 333, no. 2, pp. 502-507, 2005.

[73] T. Kojima, M. Murata, M. Go, D. C. Spray, and N. Sawada, "Connexins induce and maintain tight junctions in epithelial cells," Journal of Membrane Biology, vol. 217, no. 1-3, pp. 1319, 2007.

[74] Y. Nanke, N. Kamatani, T. Okamoto, H. Ogiuchi, and S. Kotake, "Irsogladine is effective for recurrent oral ulcers in patients with Behcet's disease: an open-label, single-centre study," Drugs in R \& D, vol. 9, no. 6, pp. 455-459, 2008.

[75] A. Hara, T. Murata, R. Uemura, et al., "Identification of connexins in human oral mucosa and therapeutic effect of irsogladine maleate on aphthous stomatitis," Journal of Gastroenterology, vol. 34, no. 1, pp. 1-6, 1999.

[76] T. Yoshida and M. Hirakata, "Therapeutic benefits of irsogladine maleate on aphthous stomatitis induced by methotrexate in rheumatoid arthritis," Journal of Rheumatology, vol. 30, no. 9, pp. 2082-2083, 2003.

[77] A. S. Tang, P. J. Chikhale, P. K. Shah, and R. T. Borchardt, "Utilization of a human intestinal epithelial cell culture system (Caco-2) for evaluating cytoprotective agents," Pharmaceutical Research, vol. 10, no. 11, pp. 1620-1626, 1993.

[78] J. Rattan, M. Schneider, N. Arber, M. Gorsky, and D. Dayan, "Sucralfate suspension as a treatment of recurrent aphthous stomatitis," Journal of Internal Medicine, vol. 236, no. 3, pp. 341-343, 1994.

[79] T. Matsuda, S. Ohno, S. Hirohata, et al., "Efficacy of rebamipide as adjunctive therapy in the treatment of recurrent oral aphthous ulcers in patients with Behcet's disease: a randomised, double-blind, placebo-controlled study," Drugs in $R \& D$, vol. 4, no. 1, pp. 19-28, 2003.

[80] T. Suzuki, N. Yoshida, N. Nakabe, et al., "Prophylactic effect of rebamipide on aspirin-induced gastric lesions and disruption of tight junctional protein zonula occludens-1 distribution," Journal of Pharmacological Sciences, vol. 106, no. 3, pp. 469-477, 2008.

[81] L. Chahine, N. Sempson, and C. Wagoner, "The effect of sodium lauryl sulfate on recurrent aphthous ulcers: a clinical study," Compendium of Continuing Education in Dentistry, vol. 18, no. 12, pp. 1238-1240, 1997.

[82] B. B. Herlofson and P. Barkvoll, "The effect of two toothpaste detergents on the frequency of recurrent aphthous ulcers," Acta Odontologica Scandinavica, vol. 54, no. 3, pp. 150-153, 1996.

[83] B. B. Herlofson and P. Barkvoll, "Oral mucosal desquamation caused by two toothpaste detergents in an experimental model," European Journal of Oral Sciences, vol. 104, no. 1, pp. 21-26, 1996.

[84] J. A. Nicolazzo, B. L. Reed, and B. C. Finnin, "Assessment of the effects of sodium dodecyl sulfate on the buccal permeability of caffeine and estradiol," Journal of Pharmaceutical Sciences, vol. 93, no. 2, pp. 431-440, 2004.

[85] S. S. Natah, R. Hayrinen-Immonen, J. Hietanen, M. Malmstrom, and Y. T. Konttinen, "Factor XIIIa-positive dendrocytes are increased in number and size in recurrent aphthous 
ulcers (RAU)," Journal of Oral Pathology and Medicine, vol. 26, no. 9, pp. 408-413, 1997.

[86] C. W. Cutler and R. Jotwani, "Dendritic cells at the oral mucosal interface," Journal of Dental Research, vol. 85, no. 8, pp. 678-689, 2006.

[87] J.-P. Allam, G. Stojanovski, N. Friedrichs, et al., "Distribution of Langerhans cells and mast cells within the human oral mucosa: new application sites of allergens in sublingual immunotherapy?" Allergy, vol. 63, no. 6, pp. 720-727, 2008.

[88] J. Freysdottir, S.-H. Lau, and F. Fortune, " $\gamma \delta$ T cells in Behcet's disease (BD) and recurrent aphthous stomatitis (RAS)," Clinical and Experimental Immunology, vol. 118, no. 3, pp. 451-457, 1999.

[89] S. S. Natah, R. Hayrinen-Immonen, J. Hietanen, et al., "Increased density of lymphocytes bearing $\gamma / \delta$ T-cell receptors in recurrent aphthous ulceration (RAU)," International Journal of Oral and Maxillofacial Surgery, vol. 29, no. 5, pp. 375-380, 2000.

[90] C. L. Roark, P. L. Simonian, A. P. Fontenot, W. K. Born, and R. L. O'Brien, " $\gamma \delta$ T cells: an important source of IL-17," Current Opinion in Immunology, vol. 20, no. 3, pp. 353-357, 2008.

[91] S. R. Carding and P. J. Egan, "The importance of $\gamma \delta$ T cells in the resolution of pathogen-induced inflammatory immune responses," Immunological Reviews, vol. 173, pp. 98-108, 2000.

[92] M. I. Hirsh, N. Hashiguchi, Y. Chen, L. Yip, and W. G. Junger, "Surface expression of HSP72 by LPS-stimulated neutrophils facilitates $\gamma \delta \mathrm{T}$ cell-mediated killing," European Journal of Immunology, vol. 36, no. 3, pp. 712-721, 2006.

[93] H. K. Komori, T. F. Meehan, and W. L. Havran, "Epithelial and mucosal $\gamma \delta$ T cells," Current Opinion in Immunology, vol. 18, no. 5, pp. 534-538, 2006.

[94] A. A. Kuhl, N. N. Pawlowski, K. Grollich, C. Loddenkemper, M. Zeitz, and J. C. Hoffmann, "Aggravation of intestinal inflammation by depletion/deficiency of $\gamma \delta$ T cells in different types of IBD animal models," Journal of Leukocyte Biology, vol. 81, no. 1, pp. 168-175, 2007.

[95] V. Kunzmann, B. Kimmel, T. Herrmann, H. Einsele, and M. Wilhelm, "Inhibition of phosphoantigen-mediated $\gamma \delta \mathrm{T}$ cell proliferation by $\mathrm{CD} 4{ }^{+} \mathrm{CD} 25^{+}$FoxP3 + regulatory T cells," Immunology, vol. 126, no. 2, pp. 256-267, 2009.

[96] K. Marakoglu, R. E. Sezer, H. C. Toker, and I. Marakoglu, "The recurrent aphthous stomatitis frequency in the smoking cessation people," Clinical Oral Investigations, vol. 11, no. 2, pp. 149-153, 2007.

[97] I. Berlin, "Endocrine and metabolic effects of smoking cessation," Current Medical Research and Opinion, vol. 25, no. 2, pp. 527-534, 2009.

[98] J. J. Malago, J. F. J. G. Koninkx, and J. E. van Dijk, "The heat shock response and cytoprotection of the intestinal epithelium," Cell Stress and Chaperones, vol. 7, no. 2, pp. 191199, 2002.

[99] M. Maes, D. R. Van Bockstaele, A. van Gastel, et al., "The effects of psychological stress on leukocyte subset distribution in humans: evidence of immune activation," Neuropsychobiology, vol. 39, no. 1, pp. 1-9, 1999.

[100] A. Buske-Kirschbaum, M. Ebrecht, S. Kern, and D. H. Hellhammer, "Endocrine stress responses in TH1-mediated chronic inflammatory skin disease (psoriasis vulgaris) do they parallel stress-induced endocrine changes in TH2mediated inflammatory dermatoses (atopic dermatitis)?" Psychoneuroendocrinology, vol. 31, no. 4, pp. 439-446, 2006.
[101] D. M. Nance and V. M. Sanders, "Autonomic innervation and regulation of the immune system (1987-2007)," Brain, Behavior, and Immunity, vol. 21, no. 6, pp. 736-745, 2007.

[102] K. Vakharia and J. P. Hinson, "Lipopolysaccharide directly stimulates cortisol secretion by human adrenal cells by a cyclooxygenase-dependent mechanism," Endocrinology, vol. 146, no. 3, pp. 1398-1402, 2005.

[103] S. R. Bornstein, P. Zacharowski, R. R. Schumann, et al., "Impaired adrenal stress response in Toll-like receptor 2deficient mice," Proceedings of the National Academy of Sciences of the United States of America, vol. 101, no. 47, pp. 16695-16700, 2004.

[104] E. Gulcan, S. Toker, H. Hatipoglu, A. Gulcan, and A. Toker, "Cyanocobalamin may be beneficial in the treatment of recurrent aphthous ulcers even when vitamin B12 levels are normal," American Journal of the Medical Sciences, vol. 336, no. 5, pp. 379-382, 2008.

[105] I. Volkov, I. Rudoy, T. Freud, et al., "Effectiveness of vitamin B12 in treating recurrent aphthous stomatitis: a randomized, double-blind, placebo-controlled trial," Journal of the American Board of Family Medicine, vol. 22, no. 1, pp. 9-16, 2009.

[106] L. L. N. Husemoen, U. Toft, M. Fenger, T. Jorgensen, N. Johansen, and A. Linneberg, "The association between atopy and factors influencing folate metabolismml: is low folate status causally related to the development of atopy?" International Journal of Epidemiology, vol. 35, no. 4, pp. 954961, 2006.

[107] Y. Ozkan, S. Yardim-Akaydin, A. Sepici, B. Engin, V. Sepici, and B. Simsek, "Assessment of homocysteine, neopterin and nitric oxide levels in Behcet's disease," Clinical Chemistry and Laboratory Medicine, vol. 45, no. 1, pp. 73-77, 2007.

[108] A. Finamore, M. Massimi, L. C. Devirgiliis, and E. Mengheri, "Zinc deficiency induces membrane barrier damage and increases neutrophil transmigration in Caco-2 cells," Journal of Nutrition, vol. 138, no. 9, pp. 1664-1670, 2008.

[109] T. A. Mikhailov and S. E. Furner, "Breastfeeding and genetic factors in the etiology of inflammatory bowel disease in children," World Journal of Gastroenterology, vol. 15, no. 3, pp. 270-279, 2009.

[110] F. Guarner, R. Bourdet-Sicard, P. Brandtzaeg, et al., "Mechanisms of disease: the hygiene hypothesis revisited," Nature Clinical Practice Gastroenterology and Hepatology, vol. 3, no. 5, pp. 275-284, 2006.

[111] C. Vanderpool, F. Yan, and D. B. Polk, "Mechanisms of probiotic action: implications for therapeutic applications in inflammatory bowel diseases," Inflammatory Bowel Diseases, vol. 14, no. 11, pp. 1585-1596, 2008. 


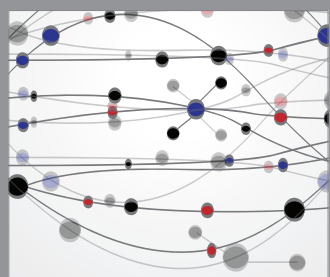

The Scientific World Journal
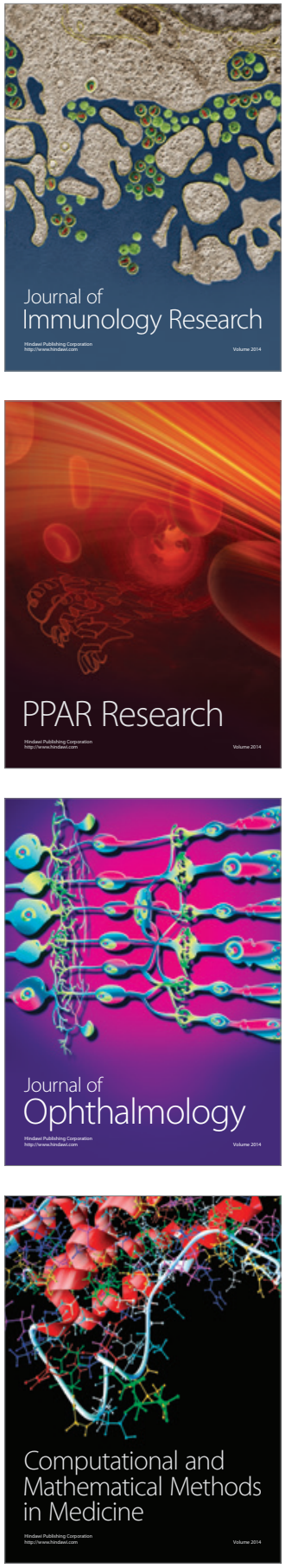

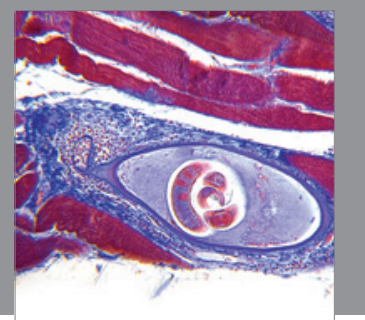

Gastroenterology

Research and Practice
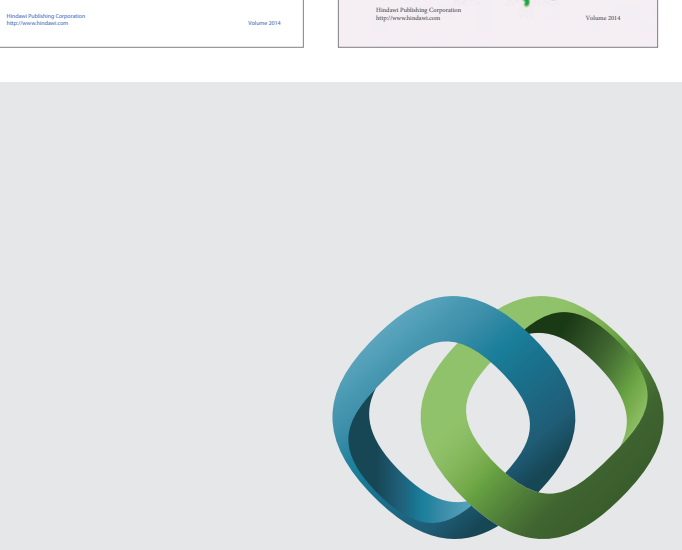

\section{Hindawi}

Submit your manuscripts at

http://www.hindawi.com
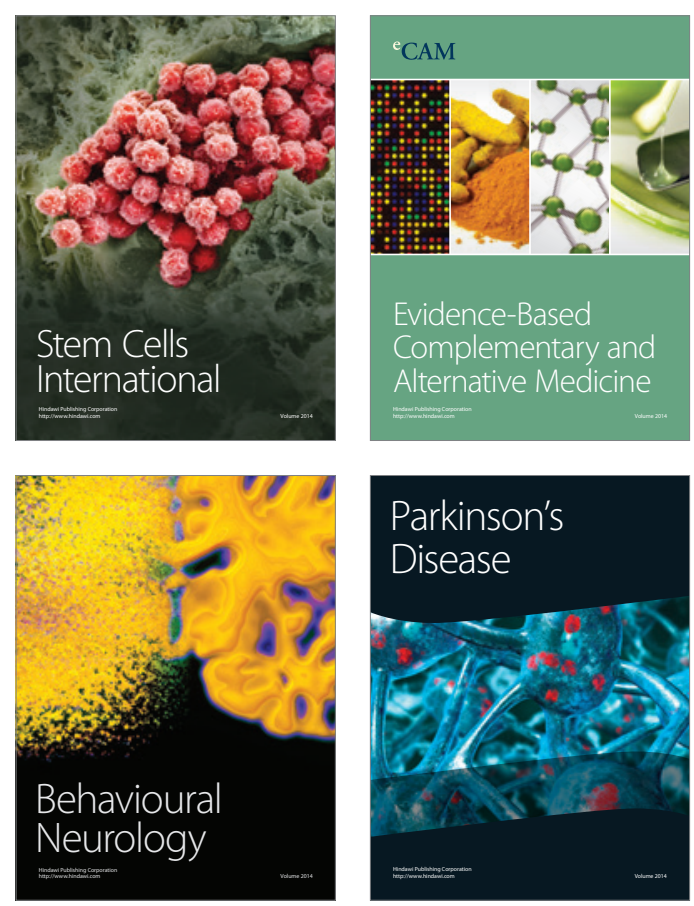

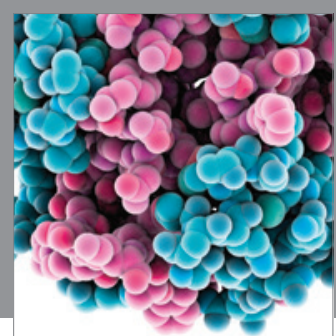

Journal of
Diabetes Research

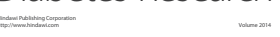

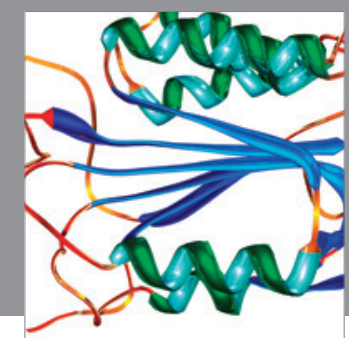

Disease Markers
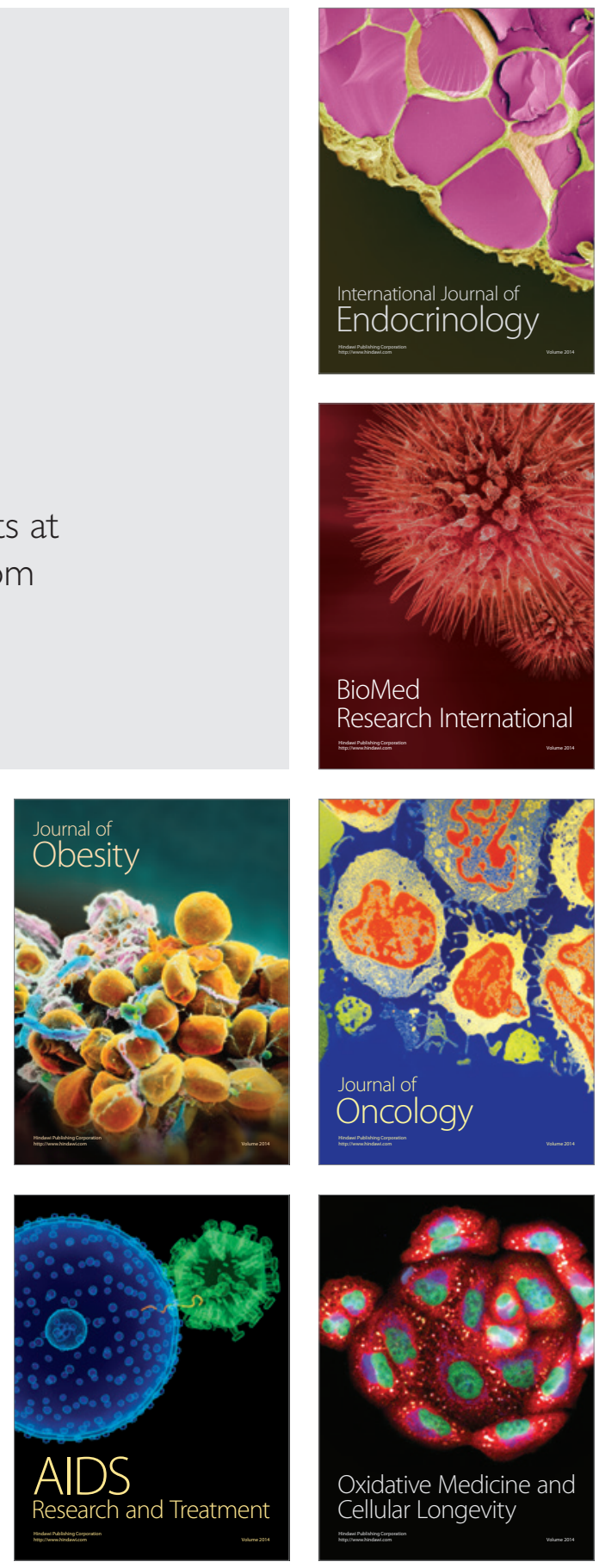